\title{
Police and Private Security Partnership in Crime Prevention, A Study of Nairobi County
}

\author{
Monda Zacharia \\ Department of Criminology and Social Work \\ Masinde Muliro University of Science and Technology \\ P.O BOX 150 - 50100 KAKAMEGA, KENYA \\ Dr. Ombachi Kipkorir (PhD) \\ Department of Emergency \& Humanitarian Assistance \\ Masinde Muliro University of Science and Technology \\ Dr. Omosa N. Mogambi \\ Department of Law and Legal Studies \\ School of Business and Management Studies \\ Technical University of Kenya
}

\begin{abstract}
With regard to the provision of security services in Kenya, Police and private security function in a mutually exclusive manner. However, it apparent that is essential to develop a formal partnership relationship, because both have several shared goals. Additionally, the private security industry also plays a significant protective role in the country. The study sought to investigate the reality of partnership between the police and the private security in Kenya. It sought to achieve this by examining the existence of any level of partnership between the private security and police in provision of security. The study also sought to establish the existing partnership between the private and public security, especially in places of common protection of public gatherings, information exchange, security and transport of money, information, and private security handing over suspected offenders to the police and how the challenges facing both private and public security providers can be curbed to enhance security. This is based on the premise that conditions for effective cooperation between the police and private security providers are not yet well developed. This study examined how co-operation in crime prevention and policing could be realized and made beneficial to all role players within the framework of a public-private security partnership. The research used both qualitative and qualitative approaches in collecting, as well as analyzing data. Additionally, both secondary and primary data were collected, with primary data being collected by use of questionnaire and interview schedule. The primary data was collected in Nairobi which was purposely sampled for its large intensity of criminal activities and security providers, both private and public. The data was analyzed using statistical package for social sciences (SPSS). The study provides deeper knowledge of local security dynamics and gives an insight into measures that could be taken to harness the energies and potentials of police and private security partnership. It also serves as a basis for future research into the country's overall strategy for providing security whilst contributing to the existing body of literature to address scarcity of data in this research area in Kenya.
\end{abstract}

Keywords: Police, Private Security, Partnership, Crime Prevention

DOI: $10.7176 /$ PPAR/11-1-01

Publication date: January $31^{\text {st }} 2021$

\subsection{Introduction}

Human security is an essential objective and a lack or compromise of it has significant negative outcomes. Therefore, the association between security and development can never be ignored. While security has been offered states to their citizens, the provision of this service by states in developing nations has been inadequate (Nalla \& Newman, 1990). As such, these states have been forced to only pay attention on state protection against internal disorders and external aggression using only he police officers and the military. These security providers work with intelligence agencies in their service provision (Nalla \& Newman, 1990). Unfortunately, these security apparatus are compromised and mainly offer protection to elites and political regimes. As such, these so called hard security organs have been majorly a burden to the citizens and are responsible for the socio-economic and physical needs of the citizens.

Maintenance of safety and good order in society is now being carried by organizations conventionally known as 'police.' However, we are witnessing a growing trend towards the use of privately funded organizations commonly called 'private security' to fill the security gaps that the public providers cannot. Whereas this advancement may be concerning for some quarters, the assignment of privately funded organizations to offer protection is not something new. As a matter of fact, this approach precedes the instituting of government administered and community-funded police services (Nalla \& Newman, 1990). For instance, in Britain, for more 
than 50 years now, the private security industry has been increasingly growing. A few years ago, private security organizations were limited to the sideline of several domestic security sectors. Here, they were generally despised by the public police, ridiculed by the fourth estate and disdained by the common citizens (Loader \& Walker, 2007). However, now private security employees are more than the public security providers in several industrial countries. These officers also carry out an array of frontline law and order roles, including, policing mega functions, safeguarding significant infrastructure, and carrying out anti-terrorist investigation functions (Loader \& Walker, 2007). In the span of hardly five decades, the industry has grown from relative insignificance to universal eminence.

Collaboration between private security businesses and government law enforcement agencies in offering security services to the nations is the likely the best approach to containing issues of insecurity in the country. The government of Kenya has establishments assigned the responsibility of managing insecurity. Although these institutions may be doing their best to protect its citizens against the effects of crime, without the support of private security provider, they cannot manage security problems effectively. On their own capacity, the public security providers attempt to manage security issues but crimes still persist and continue soaring. Some key areas call for the cooperation between the private providers and police given that the security environment is continuously evolving and becoming riskier. Offenders are becoming smarter and are employing more sophisticated techniques of carrying out criminal activities. Effective security management, therefore, calls for changing olden perspectives and outlining new approaches, with security being redefined as a by-product of a broader-ranging endeavor aiming to make these security agencies more adaptable to the ever-evolving risk atmosphere. Cooperation between private and public is among the sure ways of doing this.

\subsection{Statement of the Problem}

In the Kenyan context, crime and security issues are reflected as apprehensions of the citizens, with the Kenya Poverty reduction Strategy Paper indicating that insecurity is among the lead problems that have been pinpointed by several Kenyan communities as a basis for underdevelopment and poverty. Similarly, the Kenya Economic Recovery Strategy for Employment (2003-2007) affirms that for economic growth to be attained there is a need to address insecurity, safety, and rule of law. Efficient law enforcement, guaranteeing of law and order, and maintenance of public safety, are therefore, key to economic development, eradication of poverty, and the general improvement of social life.

Notably, as the problem of insecurity upsurges in the country more individuals and organizations are seeking help from private security businesses to promote their safety, that of their properties and families, and the security of their business premises. Consistent attacks on individuals and business have upset business feasibility, economic solidity, and in turn, the stability of communities, adversely. Moreover, the general security of the country has been affected adversely in the recent years with a growth in car-jacking, kidnappings, burglaries, and bank robberies among other criminal activities. While the government has assigned public security agencies the primary responsibility of offering security services to its citizens, a rise in demand for these services has led to the need to seek additional services from private providers. Most militia and vigilante groups arise from not-for-profit neighborhood groups that are meant to fill in the security gaps. While their intentions may be good at the beginning, they ultimately turn out to be security threats to their communities. Therefore, private security companies may be used to fill the security gaps experienced in neighborhoods. However, their services can only be available to individuals, communities, and firms that are willing and can pay for them.

However, all is not lost as collaboration between the private security and police can enhance the provision of security and handling of all law enforcement activities. While working in isolation to a large extent, the two groups have not been able to effectively provide security and curb criminal activities. The current study sought to find out the level of collaboration between the public and the private providers, their cooperation and regulation, as well as the barriers they face in their work. The study also examined how collaboration in crime prevention and policing may be attained and made useful to every role player within the structure of a private-private partnership that involves the private providers and the police.

\subsection{Study Objective}

The study objective was to examine the existing partnership between the police and private security in provision of security.

\subsection{Justification of the study}

The study will deliver profound knowledge of homegrown security changing aspects and provide an understanding into steps that may be taken to utilize the potentials and energies of police and private security partnership. In this disposition, it might be of significance to policy makers assigned to Kenya's security sector to improve on effective delivery of security in the country. The information will also serve as a foundation for future examination into the country's general plan for offering security while adding to the available body of literature to tackle the shortage of data in this area of research in Kenya. 


\subsection{Literature Review}

Empirical, theoretical and conceptual literature was reviewed in relation to the police and private security partnership

\subsubsection{The Police and private security partnership}

Partnerships between the private security and the public law enforcement have advanced afar the traditional perception of the private security having to supplement police in street patrols. Public-private collaboration in the provision of security is imperative for effective offering of these services, protection of the nation's essential infrastructure, and for handling other crime issues that disturb neighborhoods, residents, and companies. In any civilized society, the demanding task of maintaining law and order can be better rounded out by the services of disciplined and well-trained private guards. Private security ventures are now a key feature in Africa and across the world (Mtuku, 2007). There is a continuous increase in the number of partnerships across the world, calling for more studies in the subject.

In order to create policies to promote this practice, a number of government institutions are using findings from recent researches in the field. Despite the benefits that come with the cooperation between the police and private security, some people, especially the police are cynical about the partnership and not ready to embrace the idea. The investigation indicates that the collaboration between private providers and the police has been successful in reducing the crime rate in a number of countries (Prenzler, 2009).

The cooperation between the public police and the private actors is crucial in guaranteeing an effective delivery of security services (Private Officer International, 21 April 2013). Although Kenya is characterized by high levels of crime, there is exceedingly low collaboration and harmonization between the two entities. A lack of a consistent policy framework to enhance the private security-public police relationship and the absence of clear regulatory framework for the private security has undermined the cooperation between the private security and the public police.

The absence of the legal framework and the lack of policy consistence are partially a result of the varying levels of the jurisdiction of police making specific bargains with the private security organizations in their area (Abrahamsen \& Williams, 2005). To some extent, it is due to the changes in the leadership of the police force and the process of police reforms that are underway (Abrahamsen \& Williams, 2005). For these two reasons, currently there is little official cooperation between the private and the public security entities in the provision of security services to the country.

The absence of a clear guidance from the government and the police regarding the work of the private security in enhancing the security of the Kenyan citizens has worsened the situation. Additionally, there is no clear definition of the connection between the private security and the public police in enhancing the provision of security services.

The general association between the two bodies is that of suspicion and competition. A high level of suspicion between the two bodies exists with the police having an inclination of regarding the private security guards as often lawbreakers (Abrahamsen \& Williams, 2005). On the other hand, the private security providers feel that the police are often involved in criminal activities. This kind of mistrust between the two bodies has created rifts, which have adversely affected cooperation between the two security organs in fighting crime in the country. The competition between the bodies has also affected collaboration between the two security providers negatively with each regarding itself as superior to the other. Instead of working to complement each other, they consider each other as rivals.

Although a number of various forms of cooperation exist between the police and the private security providers, most of them are ad-hoc and not formalized. There is especially collaboration with the Administration police division, which is a force that is meant for leasing to customers including supermarkets, banks, embassies, and private security companies (Abrahamsen \& Williams, 2005). Sometimes the private security providers hire the administration policed for Cash-in-Transit at a relatively high cost. This high cost of hiring the Administration police officers render the arrangement unaffordable for many companies thereby opting for the poorly trained security guards. Apart from the administration police, the paramilitary General Service Unit (GSU) personnel are situated in a number of embassies and other high-risk areas, where they cooperate with the private security providers (Abrahamsen \& Williams, 2005).

However, on a daily basis the most essential type of collaboration between the private security and the public police takes place in the form of responding to alarms and incidents from customers. Given that the private security workforce in the country is without arms, the private security providers rely heavily on the public police to provide a backup in case of a serious incidence that involves firearms and/or other weapons.

The current informal and ad-hoc connection between the private security companies and the public police seems to be ineffective in combating crime in the country. Whereas it appears that some private security establishments have managed in taking into service police department officers on their guard vehicles through casual arrangements, most private security providers carry out patrols in the absence of any armed police or support (Abrahamsen \& Williams, 2005). It is suffice to conclude that the cooperation that exists between the private and 
public security providers is fundamentally of a casual nature, relying on personal contacts as opposed to any official or formalized contract or relationship. In order, to minimize the random and ad-hoc kind of the relationship, there is a need to formalize the relationship through both legal and policy frameworks.

\subsubsection{Private security services in Kenya}

A substantial portion of private security market is operated by limited large sized transnational establishments that provide reasonably higher standard levels of service compared to the minor companies. According to Wakefield (2005), this industry remains principally unregulated by the government allowing industry players to lower their service standards. Moreover, Wakfield notes that out of over 2000 security firms operating in the country, only 21 were operating under the Kenya Security Industry Association (KSIA), which is an alliance of private security companies in the country. The implication is that most of these companies fall outside the confines of the industry's self-regulation apparatuses. Additionally, a large number of these security firms are not registered by the relevant government authorities charged with business registration, meaning that they operate illegally. No specific government agency is tasked with the duty of regulating the industry. There also lacks a policy framework to set guidelines and rules for industry. Consequently, several private security establishments pay minute attention to work ethics, labor, and service standards.

More often, employees are young, ineffectively trained, poorly equipped, incompetent, and do not have the necessary motivation to carry out their duties effectively. Wairagu et al (2010) found out that most of the workforce includes fresh school leavers whose ages ranged between 18 and 30 years. Further, the survey found out that the majority of the employees have a secondary level education or less. Moreover, the researchers observed that most of the guards lacked insurance, leaving their dependents vulnerable in case of a fatality or an injury. Consequently, employees of this sector are dissatisfied and usually collude with offenders to rob their clients and employers. For example, in 2009, there were three different instances of G4S Company being raided while transferring money. In all the cases, it was suspected that some members of the company collaborated with criminals to execute the unlawful activities.

\subsubsection{The Need for private security in Kenya}

Private security in Kenya is a necessity given the increased demand for law enforcement and the lack of adequate police to provide the much needed protection. According to Mkutu et al (2007), efficient law enforcement, the upholding of public safety, as well as the assurance of property and life protection are necessary to economic growth as well as the establishment of a supporting environment for the private sector-led development and growth. Problems arising as barriers to the offering of high-quality security service include delayed response to crime incidents, poor crime scene management, low rates of detection and prevention of crime, poor Human Resource Management systems and policy, and understaffed police service. Other challenges include inadequate resources, poor conditions and terms of service, and bureaucratic purchasing processes in the acquisition of security equipment.

\subsubsection{The need for regulation}

The lack of strong institutional mechanisms for ensuring that security apparatus are held accountable and ensuring that the rule of law is upheld, should receive significant attention. Initially, formal approaches for ensuring police accountability were confined to the office of the president (Nalla et al., 2006). As a result, the police were vulnerable to interference by influential and powerful individuals who are not within the regular chain of command and formal accountability mechanisms, including wealth business people and politicians. These individuals have always used the police for their personal and political agenda, more often contravening the interests of the people of Kenya (Nalla et al., 2006). In order to enhance their financial and social well-being as well as being in good terms with the politicians, the police have always established strong ties with the politicians, bureaucratic individuals, and their associates even when their orders contravene the law or do not advance the interest of the general public (Nalla et al., 2006). As such, they have not been able to offer their best in law enforcement.

There is, therefore, a need for the institution of fair, transparent, and efficient, apparatuses, both within and without the police force, for investigating as well as punishing misconduct. The reliance on controlling patrons results in extensive impunity, which is the chief enemy of accountability. With such an approach public security providers may engage in crime, human rights abuse, and misconduct while being confident they will never be held accountable for their misdeeds. In the nonexistence of operational investigations and punishment of mechanisms of police misconduct, impunity exists. Impunity also exists whenever potent people outside the conventional chain of command may, through their benefaction, shield some favored security personnel from investigation and punishment. For instance, the hiring, training, deployment, equipping, and elevation of Kenya Police Reserve (KPR) have become a potential and significant ground for corruption. Therefore, there is a need to restructure police operations if it is to attain effective service delivery.

\subsubsection{Theoretical explanation}

The research was based on concepts from two main theories namely; the fiscal constraint theory and structuralism theory.

The theory of constraints (TOC) is a general management theory presented by Eliyahu M. Goldratt in his 
1984 book The Goal. The philosophy is geared toward helping organizations to continually attain their goals. Later on in 1997, he adopted this concept in his other book Critical Chain. This theory is a management model that perceives any management scheme as being restrained in attaining more of its objectives through a very minute number of limitations. Usually, there is at least a single constraint, and TOC employs a focusing process that helps identify the limitation and reorganize the entire organization around this constraint.

There are two major strands within the constraint theory. One of these strands is the liberal democratic strand. The strand attributes the phenomena to the effects of the unavailability of resources for government agencies. The other one is the radical strand that perceives the phenomenon as the unavoidable occurrence of the capitalist logic, which has changed the security need into a money-making commodity.

In the current study, the constraint theory will assist show the effects of any existing barriers between the public and private security providers in terms of equipment sharing, legal policy framework, and sharing of skills in a collaborative tactic to crime prevention, which are unquestionably the major objective of each of the entities.

On the other hand, the functionalist theory originates in Emile Durkheim's work. Durkheim was particularly interested in how society remains quite stable or social order is achievable. Functionalism interprets every segment of society in terms of how each leads to the steadiness of the entire society. He recognized that society is not just the sum of its parts but that every segment of it is responsible for the entire society's stability. The various parts are principally the institutions of a society. Each of them is organized to accomplish varying needs, with each having given results for the shape and form of society. All these parts depend on each other.

Functionalism stresses the order and the consensus that exist in a society, paying attention on common public values and social stability. From this point of view, disorganization in a given system, including deviant behavior, results in shifts because societal elements have to adjust to attain stability. When one part of the system is not working or is dysfunctional, it affects all other parts and creates social problems, which leads to social change. In basic terms, this theory proposes that societies are a unified mass made up of separate organizations that all have different agendas. All these parts are connected with each other to advance their own agendas, but are also interconnected together to support each other and maintain the general social well-being and culture. The theory, however, attributes the shift to the growing significance of private conflict resolution and justice within the private sphere and without reference to an official system.

In the current study, the functionalism theory shows the need for the two entities of the system namely, the Kenya police as one organ and private security providers as another organ of the security system in Kenya functioning together to attain a zero rate in offence, which will imply a secure Kenya.

\subsection{Methodology}

The study adopted a descriptive survey design to determine police and private partnership in crime prevention in Nairobi County. Survey research is a kind of descriptive research which embraces both fact finding and descriptive enquiries of varying types. In this study, the study area was Nairobi County whose coverage is about $684 \mathrm{sq} \mathrm{km}$. The County has nine sub-counties namely, Dagoretti, Westlands, Kasarani, Starehe, Langata, Kamukunji, Njiru, Makadara, and Embakasi. Nairobi city has the highest population among all the cities in East Africa. Its total population is estimated at around 3 million. The county was purposively chosen because of its significant concentration of criminal activities in addition to a large number of security providers, both private and public.

This study had two sets of study population, that is, private security providers and public security providers. This involved one hundred and thirty five (135) personnel who were identified from the private security sector across all the nine sub-counties in Nairobi and one hundred and thirty five (135) police officers of various ranks within the Kenya Police Service, drawn from all the nine sub-counties in Nairobi. Kenya police officers refers to personnel appointed to serve as a police officer in the Kenya Police Service. The Kenya Police Service was established under Article 243(1) of the Constitution of Kenya.

The study employed questionnaires as a data collection tool and interview as a data collection method.

To enhance content validity, the researcher carried out a pilot study. This exercise involved selecting $10 \%$ of the sample size and administering the questionnaires to them. This helped the researcher to identify vague questions and subsequently rephrased them. The researcher also had an opportunity to clarify instructions and improve other deficiencies in the questionnaires such as numbering and spacing.

The data was processed through the Statistical Package for Social Sciences (SPSS) software before analysing it. The research generated both qualitative and quantitative data. The quantitative data obtained from closed ended questions was analysed using descriptive statistics through calculating frequencies, mean scores, and percentage. The data was then presented using charts, graphs, and tables. On the other hand, qualitative data obtained from open-ended questions was presented thematically in narrative tables and forms.

\subsection{Study Findings}

Both descriptive and inferential statistics are presented; 


\subsubsection{Response Rate}

The study targeted 270 respondents with 135 being police officers from the National Police Service and 135 officers from private security firms within Nairobi County. Out of the respondents targeted, the study realized 117 questionnaires from police officers and 124 questionnaires from officers in private security firms, resulting in an actual sample of 241 respondents. As such, the study attained a response rate of $89.26 \%$. Mugenda and Gitau (2009) assert that a response rate of at least $70 \%$ is excellent for generalizing findings from a given sample onto the entire study population from which the study sample was obtained. Regarding the current study, the response rate was excellent, meaning that the study findings can be generalized.

\subsubsection{Demographic Characteristics of Respondents}

This research sought to examine basic information from respondents that would be influential to the study variables. Some of the variables that were of interest to the current study were age range of respondents, gender, employer, length of service, salary range and position in the organization. Findings are presented in the following section. Participants were requested to specify their age ranges and findings were presented in table 1 .

\section{Table 1: Age range of respondents}

\begin{tabular}{lcc}
\hline Age Range & Frequency & Percentage (\%) \\
\hline $20-30$ years & 47 & 19.50 \\
$31-40$ years & 102 & 42.32 \\
$41-50$ years & 56 & 23.24 \\
Over 50 years & 35 & 14.52 \\
Total & $\mathbf{2 4 1}$ & $\mathbf{1 0 0 . 0}$ \\
\hline
\end{tabular}

Resultss in table 1 indicated that $42.32 \%$ of the respondents were between 31 and 40 years of age while $23.24 \%$ were aged between 41 and 50 years. It was also found out from the research findings that $19.5 \%$ of the respondents were between 20 and 30 years of age and $14.52 \%$ were aged above 50 years. Respondents for the study were mature individuals capable of making good judgement in the context of the study constructs under investigation.

Respondents were also requested to state their current employer and the findings were presented in figure 1

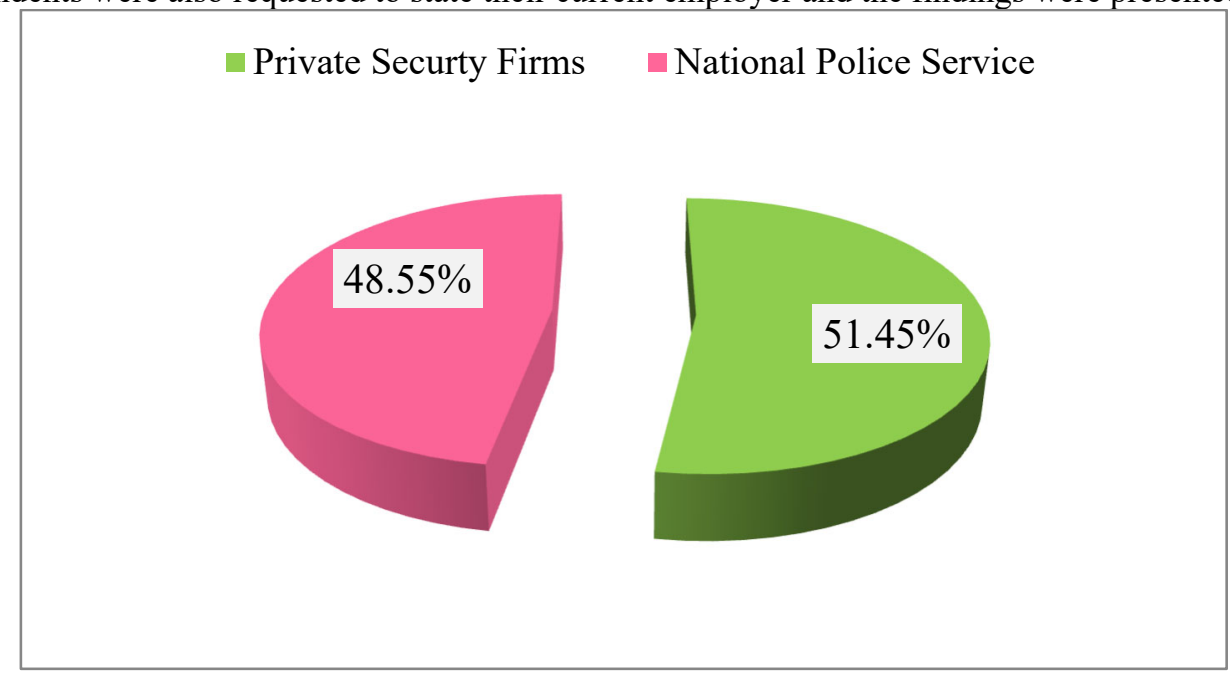

Figure 1: Respondents' Current Employer

Findings in figure 1 show that $51.45 \%$ of the research respondents were obtained from private security firms while $48.55 \%$ were drawn from the national police service. The study made deliberate attempts to sample respondents from across the targeted respondents in a manner that brought to the study the desired characteristics of both study populations.

The study also sought to investigate how long respondents had been in employment and findings were presented in table 2 .

Table 2: Length of Service of Respondents

\begin{tabular}{lcc}
\hline Length of Service & Frequency & Percentage (\%) \\
\hline Less than 4 years & 25 & 10.37 \\
$4-10$ years & 51 & 21.16 \\
$11-20$ years & 42 & 17.43 \\
$21-30$ years & 87 & 36.10 \\
Over 30 years & 36 & 14.94 \\
Total & $\mathbf{2 4 1}$ & $\mathbf{1 0 0 . 0}$ \\
\hline
\end{tabular}


Results in table 2 show that $36.1 \%$ of the study participants had been in employment for 21 to 30 years while $21.16 \%$ had been employed for 4 to 10 years. It was also established based on the study findings that $17.43 \%$ of the respondents had been employed for between 11 and 20 years, 14.94\% for over 30 years and 10.37\% had been in employment for less than 4 years. This is a clear indication that a large number of the respondents had immense work experience in the security sector and would understand the study constructs and provide responses that appropriately address the study objectives.

Study constructs relating to partnerships between the two entities in provision of security were analyzed using Chi- Square and results presented in table 3

Table 3: Chi-Square Results for the Partnership between Police and Private Security

\begin{tabular}{|c|c|c|c|c|c|}
\hline & Value & Df & $\begin{array}{l}\text { Asympt. Sig. } \\
(2 \text {-sided })\end{array}$ & $\begin{array}{l}\text { Exact Sig. } \\
(2 \text {-sided })\end{array}$ & $\begin{array}{l}\text { Exact Sig. } \\
(1 \text {-sided })\end{array}$ \\
\hline Pearson Chi-Square & $17.691^{\mathrm{a}}$ & 1 & .002 & & \\
\hline Continuity Correction $^{\mathrm{b}}$ & 4.884 & 1 & .003 & & \\
\hline Likelihood Ratio & 17.425 & 1 & .003 & & \\
\hline Fisher's Exact Test & & & & .003 & .003 \\
\hline Linear by Linear Association & 17.229 & 1 & .002 & & \\
\hline $\mathrm{N}$ of valid cases & 241 & & & & \\
\hline
\end{tabular}

0 cells (.0\%) have anticipated count of less than 4. The least projected count is 48.03 .

Findings in table 3 indicate a statistically significant association between the national Police Service and Private Security establishments in the provision of security in Nairobi County $\left(X^{2}=17.691 ; \mathrm{df}=1 ; \mathrm{P}<0.05\right)$. This indicates that a significant partnership exists between the public and private security actors in the provision of security services in Nairobi County.

In order to establish the relationship between the National police service and private security firms in providing security services in Nairobi County, study constructs relating to the partnership were subjected to Pearson Product Moment Correlation Coefficient. The findings were presented in table 4.

Table 4: Relationship between police and private Security Organization in providing Security Services

\begin{tabular}{lll}
\hline National Police Service & Private Security Companies \\
& Sig. (2-tailed) & $.735^{* *}$ \\
& N & .026 \\
& 241
\end{tabular}

**Correlation is significant at 0.0 level (2- tailed)

*Correlation significant at 0.01 level $(2$ - tailed)

Source: Research data, 2015.

Findings in table 4 show a statistically significant positive correlation between the collaboration between the police service and private actors in providing security in Nairobi county $\mathrm{s}(\mathrm{r}=0.735, \mathrm{P}<0.05)$. This indicates that both the police and private security guards play a complimentary role to each other as regards providing security services.

In order determine the extent of agreement between respondents from the National police service and those from private security firms as regards degree of collaboration between police and private actors in providing security services, a two sample independent t-test for equality of means was calculated at the significance level of $95 \%$. The findings are presented in table 5 .

Table 5: t-Test on mean agreement for respondents from the police and private security firms

\begin{tabular}{|l|l|l|l|l|l|l|l|}
\hline & \multicolumn{2}{|l|}{$\begin{array}{l}\text { Levene's test for } \\
\text { Equality of Variances }\end{array}$} & \multicolumn{2}{l|}{ t-test for Equality of Means } \\
\hline & & & & & Sig.(2- \\
Thean & $\begin{array}{l}\text { Mean } \\
\text { Difference }\end{array}$ & $\begin{array}{l}\text { Standard Difference } \\
\text { Error }\end{array}$ \\
\hline $\begin{array}{l}\text { Equal Variances } \\
\text { Assumed }\end{array}$ & 0.371 & .508 & 2.218 & 28 & .051 & 2.945 & 1.374 \\
\hline $\begin{array}{l}\text { Equal Variances } \\
\text { not Assumed }\end{array}$ & & & 3.009 & 27.417 & .058 & 2.971 & 1.399 \\
\hline
\end{tabular}

$t$-critical $(d f=2,28, t=2.39, p \leq 0.05) ;$-calculated $(d f=2,28, t=2.218, p=0.051)$

Study findings in table 5 indicate that there is a statistically insignificant difference in the mean response on study constructs seeking to establish the extent of co-operation between the police and private security in providing security services in Nairobi County $(\mathrm{t}=2.218, \mathrm{P}>0.05, \mathrm{df}=2,28)$. This is further indicated with the critical value of $t$, which is 2.39 being bigger than the calculated value of $t$, which is 2.218 . This implies that the variances in the responses between respondents from the national police service and those from private security companies as regards extent of co-operation and collaboration in provision of security services were largely in agreement. Since 
the difference in mean responses to items on co-operational between the police and private security were not statistically significant, same strategies on how to maximize co-operation and collaboration between police and private security organizations in providing security may work for both categories of the security sector.

Findings of the study are deliberated in reference to results from empirical studies on the collaborations between government police and private actors in security provision. In a study by the organization Private Officer International (2013), the cooperation between the public police and private actors is critical in guaranteeing an effective delivery of security functions. It is essential to note that there is a lack of a consistent policy framework to enhance the private security-public police relationship and the lack of vibrant regulatory support for the private security has undermined the collaboration between the private security and the public police.

The absence of the legal framework and the lack of policy consistence are in part a result of the various levels of the jurisdiction of police making particular bargains with the private security organizations in their area (Abrahamsen \& Williams, 2005). To some extent, it is due to the changes in the leadership of the police force and the process of police reforms that are underway (Abrahamsen \& Williams, 2005). For these two reasons, currently there is little official cooperation between the private sector and the public police in the provision of security services to the country.

The nonexistence of a clear guidance from the government regarding the role of the private security in enhancing the security of the Kenyan citizens has worsened the situation. Additionally, there is no clear definition of the relationship between the public and the private actors in enhancing the provision of security services.

Although a number of varying forms of cooperation exist between the police and the private security providers, most of them are ad-hoc and not formalized. There is especially collaboration with the Administration police division, which is a force that is meant for hire to customers including supermarkets, embassies, banks and private security providers (Abrahamsen \& Williams, 2005). Sometimes the private security providers hire the administration policed for Cash-in-Transit at a relatively high cost. This high cost of hiring the Administration police officers render the arrangement unaffordable for many companies thereby opting for the poorly trained security guards. Apart from the administration police, the paramilitary General Service Unit (GSU) personnel are situated in a number of embassies and other high-risk areas, where they cooperate with the private security providers (Abrahamsen \& Williams, 2005).

However, on a daily basis the most essential form of cooperation between the private security and the public police takes place in response to alarms and incidents from customers. Given that the private security employees in Kenya are unarmed, the private security providers rely heavily on the public police to provide a backup in case of a serious incidence that involves firearms and/or other weapons.

\subsection{Conclusions}

The objective of the study sought to examine the existing partnership between the police and private actors in the provision of security. Findings of the investigation revealed a statistically significant association between the National Police Service and Private Firms in provision of security in Nairobi County. To establish the association between the National police service and private security providers in Nairobi County, Pearson Product Moment Correlation Coefficient was performed and research findings revealed a statistically significant positive correlation between the national police service and private companies in offering security in Nairobi County. Based on the above finding, it is concluded that there is a significant partnership between the national police service and private security companies in provision of security services in Nairobi County.

\subsection{Recommendations}

Considering the results and conclusion of the study, the following recommendations are made;

Collaboration between the private security companies aims to attain public security and safety by establishing cooperation between public security agencies and the private players, and developing public confidence and trust in the police. This is expected to enhance accountability, promote performance and in the end add to the decrease in crime and associated terror. Interactions between the private providers and the state are becoming increasingly more intricate. Given that the public providers are usually regulators of private security as well as potential competitors in policing service delivery, the dual relationship raises issues of conflict of interest. However, in several circumstances private security and police have quite dissimilar policing functions and are not actually competing with each other.

The National police have sometimes been perceived to be corrupt and this has led to a more increased roll of private security establishments as an effective alternative. With decentralization, however, police are losing their established monopoly in the provision of policing services. As such, it is not surprising that the police are hesitant, for instance, to share information with the private players. Due to societal advancements, it is particularly important now more than ever before to utilize all available approaches to fight crime.

This fight against crime cannot happen effectively in the absence of the help of private security and effective collaboration between the public and private establishments. Moreover, as partnerships between the police and 
private security firms should be established urgently, there is also a need for the establishment of partnerships among the private security firms themselves. Some of the approaches to attaining these are enhancing awareness of the need to collaborate and putting in place a memorandum of understanding.

\section{REFERENCES}

Abrahamsen, R. \& Williams, M.C. (2005). The globalization of private security. Country report -Kenya .

Nalla, M. and Newman, G. (1990) A primer in private security, Harrow and Weston, New York.

Fisher, R.J. and Green, G. (1992) 'Security: Its Problems, Its Future' Introduction to Security, ButterworthHeinemann, Stoneham, MA, USA.

Bowman, R. (2010). Interview with Resident Legal Advisor. Nairobi, Kenya.

Cottrell, P. A., \& Deangelis, G. (1999). A working relationship. Law \& Order, 47(10), 95-97. Retrieved from http://search.proquest.com/docview/197210858?accountid=35812

Dempsey, J. S. (2010). Introduction to private security. Belmont, CA: Wadsworth Cengage Learning.

Fleming, J., \& Wood, J. D. (2006). Fighting crime together: The challenges of policing and security networks. Sydney: University of New South Wales Press.

Green, D. R. (1998). Joining forces against crime. Security Management, 42(5), 95-98. Retrieved from http://search.proquest.com/docview/231188194? accountid=35812

Hess, K. M. (2009). Introduction to private security. Belmont, CA: Cengage Learning.

Jager, Thomas, and Gerhard Kummel (Eds.). (2007). "The Private Security Industry in Kenya: Issues and Challenges" in Private Military and Security Companies: Chances, Problems, Pitfalls and Prospects. Wiesbaden: VS Verlag fur Sozialwissenschaften. pp.177-201

Kenya Tourism Fedearation (2012). KTF statement on security in Kenya. Retrieved from http://www.hemingways-expeditions.com/wp-content/uploads/2012/05/KTF-STATEMENT-ON-

SECURITY-IN-KENYA.26th-April2.pdf

Kenya, Transparency International (2008). The Kenya Bribery Index. Nairobi, Kenya.

Keriga, L., \& Bujra, A. (2009). Social policy, development and governance in Kenya:A Profile on Crime and Insecurity in Kenya. Nairobi: Development Policy Management Forum.

Levinson, D., \& Sage Publications, Inc. (2002). Encyclopedia of crime and punishment. Thousand Oaks, Calif: Sage Publications.

Maina, E., Oboka, Wycliffe, Majong'o, Julius. (2004). History and Government (3 ed.). Nairobi: East African Educational Publishers Ltd.

Miller, L. S., Hess, K. M., \& Orthmann, C. M. H. (2011). Community policing: Partnerships for problem solving. Australia: Delmar Cengage Learning.

Mokwa, J., \& Stoehner, T. W. (1995). Private security arches over st. louis. Security Management, 39(9), 94-94. Retrieved from http://search.proquest.com/docview/231159126?accountid=35812

Mtuku, K. (2007). The private security industry in Kenya: Issues and challenges. Private Military and Security Companies. pp 177-201. VS Verlag für Sozialwissenschaften

Shearing, C.D. \& Stenning, P.C. (1983) 'Private Security and its Implications: A North American Perspective' Proceedings - Training Project No. 49/5 Policing and Private Security Australian Institute of Criminology, Canberra.

Ndungu, I. (2012). Kenya: Addressing Rising Insecurity in Kenya. AllAfrica.

Omani, T. (2010). Interview with Assistant Commissioner of Police. Nairobi.

Prenzler, T. (2009). Strike Force Piccadilly: a public-private partnership to stop ATM ram raids. Policing: An International Journal of Police Strategies \& Management, Vol. 32 Iss: 2, pp.209 - 225

Private Officer International (21 April 2013). Embracing Private and Public security collaboration. Retrived from http://privateofficernews.wordpress.com/category/policesecurity-cooperation/

Purpura, P. (2013).Security and Loss Prevention: An Introduction. Oxford: Butterworth-Heinemann.

South, N., (1988) Policing for Profit: The Private Security Sector, Sage Publications, London, 1988.

Mugenda, Olive M. and Abel G. Mugenda, 2003. Research Methods: Quantitative \& Qualitative Approaches

United Nations Human Settlements Programme. (2007). Enhancing urban safety and security: Global report on human settlements 2007. London: Earthscan.

US Department of Justice (1999). Operation cooperation: a literature review of the cooperation and partnerships between law enforcement and private security organizations. Retrieved from: http://www.ilj.org/publications/docs/Operation_Cooperation_Literature Review.pdf

Voice of America (2010). As crime in Kenya soars, police look to private security firms for help. Retrieved from: http://www.voanews.com/content/as-crime-in-kenya-soars-police-look-to-private-security-firms-for-help90943689/154131.html 